\title{
AGRICULTURE EXTENSION OFFICERS' ATTITUDE AND READINESS IN USING INFORMATION AND COMMUNICATION TECHNOLOGY IN INDONESIA
}

\author{
Purnomo Sutrisno Hadi ${ }^{\star}$, Sari Ayu Intan, Emawati Shanti, Rahayu Endang Tri, \\ Triaswati Rani Pane \\ Department of Animal Science, Faculty of Agriculture, University of Sebelas Maret, \\ Surakarta, Indonesia \\ *E-mail: sutrisnohadi@staff.uns.ac.id \\ ORCID: 0000-0002-5720-5678
}

\begin{abstract}
This research aimed to figure out the attitude and readiness of agriculture extension officers in using the Information and Communication Technology. Data collection was done through a survey with total sample 60 respondents. Data gained were primary data from questionnaire filling by respondents who were all extension officers in Food Security and Extension Implementation Agency. Data analyses used in this research were reliability and validity analysis, Fishbein's Attitude Model, and regression analysis which continued with $\mathrm{F}$ and $\mathrm{t}$ test. The results of Validity and Reliability Test gave a valid outcome with $r_{\text {cal }}>0,3$ and reliability value of $\alpha>0,6$ in all variables. Fishbein's Attitude Model test in all variables showed an answer from neutral to very positive data. Linear Regression Test resulted in an equation $Y=-6,234+0,211 X 1+0,213 X 2+0,550 X 3+0,119 X 4+1,252 X 5+0,665 X 6$. The value of determination coefficient $\left(R^{2}\right)$ was 0,816 which meant that variable variance of Information and Communication Technology acceptance could be explained by data variance of extension officers' attitude and readiness (farmer readiness, extension officers readiness, infrastructure, management support, culture support) in values of $81,6 \%$. In F test, $F_{\text {cal }}$ was $=44,683$ and was significant in $p<0,05$, which meant that the effects of extension officers' attitude and readiness to Information and Communication Technology acceptance.
\end{abstract}

\section{KEY WORDS}

Agriculture, extension officers, attitude, readiness, information, communication technology.

Indonesia is agrarian country with most of the citizens rely on agriculture sector including crops, animal husbandry and fishery as their main income source. Agricultural sector has a quite big role in supporting the country's economy and had an important role in development especially in rural area. In developing agriculture, qualified human resource was needed because human resource was the main capital to be the motor of development in an area. Government should actively participate in improving the quality of human resource to have good working skill and competency in this sector, one of the ways was through learning process in a non formal education that could be in the form of a briefing to citizens done by agriculture extension officers.

A briefing or an extension was an activity of a learning process, so the success depended on how far the process run. Thus, extension officers' role as ones who responsible in carrying out the learning activity for farmers was very important (Unang and Didin, 2011). Through extension, farmers were given knowledge, skill, an introduction to technology and innovation in agriculture and farm. The definition of extension in general meaning was social science which studied a changing system and process in an individual and society to reach a better change as hoped (Koehnen, 2011). An extension could be assumed as a form of education for adults. An extension was an involvement of a person to communicate the information consciously to help others delivering their opinions so that a right decision was gained (Akpabio et al., 2007).

Extension officers were a party that directly contacted the farmers. Extension officers were main factor to deliver knowledge to farmers. An extension was an innovation spreading and a communication media between government and the citizens in delivering knowledge 
and technology development. One of the developments which should be used by farmers was Information and Communication Technology, that was very useful to ease modern information searching and a media to communicate quickly and globally in agriculture and farm sector (Purnomo and Lee, 2010).

Two of the available Information and Communication Technology were internet and computer, which were a technology development that nowadays have become a culture and had a big influence to knowledge development. Communication and information aspects laid their basis on internet, and with the presence of internet-based technology, people would get every newest information more easily from all over the world. The development and the usage of ICT were very important in all sectors including agriculture sector. This technology was used to search information and to ease communication needed by farmers. This technology could be used to improve extensions' effectiveness and efficiency. Based on the above explanation, the aim of the research was then formulated, that was to find out the agriculture and farm extension officers' attitude and readiness to accept ICT in Indonesia.

\section{METHOD OF RESEARCH}

The research was done in Food Security and Extension Implementation Agency in Boyolali District, Central Java Province. The research was divided into two stages: presurvey and survey. Pre-survey stage was done to determine the location where to gather data and respondents. Survey stage was carried out to gather data, both primary and secondary. Primary data were gained through direct interview with respondents, while the secondary data were got from the related institutions. Respondents in this research were all agriculture extension officers in Boyolali District. Convenience sampling method was chosen to collect data, using 60 extension officers attending the ICT implementation socialization as respondents. Data collection technique was done by giving questionnaire directly to respondents at the moment of Boyolali District extension officers' coordination. Questionnaire measurement was done using Likert scale with score 1 to 5; (1) Very disagree, (2) Disagree, (3) Neutral, (4) Agree, (5) Very agree.

The data gained from respondents' answers were analyzed with quantitative descriptive analysis. There were a few data analysis held in this research. Validity analysis was to show validity level of a question instrument in the questionnaire, if $(r>0,3)$, then the question was valid. Reliability test was done to assess questions related to a measuring tool's consistency, when ( $\alpha>0,6)$, then the question was reliable (Sugiono, 2005), Fishbein's Attitude Model analysis was to score attitude and readiness of all questions' attributes (Wardani et al., 2001).

Regression analysis was an analysis to find out the influence of independent variables to dependent variables, and continued with statistic analysis using $F$ test to figure out whether all independent variables simultaneously influenced the dependent variables at significant level of $(\alpha)=1 \%$ and probability level of $<0,01$ or $<0,05$. $R^{2}$ was used to check how far the independent variables influenced the independent variables, $t$ calculated $>t$ table, so that Ho was rejected or Ha was accepted which meant significant (Gujarati, 1999), there were two classic assumption tests, namely multicollinearity test to check the correlation among independent variables in the regression model with tolerance limit should be less than 0,1 or value of VIF was not more than 10 which meant there was multicollinearity (Ghozali, 2007), heterocedacity test was done to find out if there was variant similarity of residual from one observation to another (Sunyoto, 2009).

\section{RESULTS AND DISCUSSION}

Respondents (Agriculture Extension Officers) characteristic described their condition in term of gender, age, education level, skill and their working period as extension officers, which could be seen in Table 1. 
Table 1 - Respondents Demographic Characteristic

\begin{tabular}{llll}
\hline Variables & & Frequency & Percent (\%) \\
\hline Gender & Man & 47 & 78.3 \\
Age & Women & 13 & 21.7 \\
& $20-30$ Years & 5 & 8.3 \\
& $31-40$ Years & 14 & 23.3 \\
Education & $41-50$ Years & 16 & 26.7 \\
& $>50$ Years & 25 & 41.7 \\
& S High School & 3 & 5 \\
Expertise & Vocational & 6 & 10 \\
& Machelor & 50 & 83.3 \\
& Crops & 1 & 1.7 \\
& Horticulture & 28 & 46.7 \\
& Plantation & 2 & 3.3 \\
Working experience & Forestry & 2 & 3.3 \\
& Animal Husbandry & 11 & 18.3 \\
& Fishery & 15 & 25 \\
& $0-5$ Years & 2 & 3.3 \\
& $6-10$ Years & 12 & 20 \\
& $>10$ Years & 8 & 13.3 \\
\end{tabular}

Based on Table 1, totally 60 respondents has participated. The most of the respondents were men $(78,3 \%)$. They were mostly $>50$ years old, with total of 27 persons $(41,7 \%)$, because there have not been a new recruitment for a long time and many structural employees then became extension officers. $83,3 \%$ or 50 respondents had bachelor degree, to be extension officers, a good knowledge in agriculture was really needed and the knowledge was got from the university. Respondents' skill in handling food crops was in the highest rank with total of 28 persons (46,70\%). Because food crop extension was the most needed in Indonesia as an agrarian country producing food crop, especially rice. In Boyolali District, many of the citizens were farmers, thus agriculture experts were needed to improve harvest, so that most of the extension officers had expertise in food crop. Food sustainability in an area could be realized when supported by qualified human resource and government apparatus (Departemen Pertanian, 2006). To direct citizens' attitude, extension officers as government apparatus should have basic skill in carrying out their job.

Respondents' working period was mostly more than 10 years, with total of 40 persons $(66,7 \%)$. Because of the few young extension officers and many of the extension officers still work at their 50s. One's working period would affect their seniority, even though there were not any reasons to merely rely on seniority in term of working performance when compared to ones with shorter working period (Nani, 2008).

Validity test on all items gave value of $r x y>0,254\left(r_{\text {cal }}>r_{\text {table }}\right)$ which meant that question items measuring attitude, farmers' readiness, extension officers' readiness, infrastructure readiness, management readiness, culture readiness and communication and information technology acceptance were valid. Based on Sugiono (2005), an instrument was reliable when Alpha Cronbach coefficient was $(\alpha>0,6)$. Reliability test showed a reliable result with the lowest value of 0,916 and the highest value of 0,975 .

Fishbein's Attitude Model analysis was used to find out the attitude and readiness in using the ICT. Components being analyzed using the model were measured with Likert scale. This scale enabled respondents to express their feeling intensity attitude. The six main variables in this research were stated in numerical form. And the description was stated in average score.

Fishbein's Attitude Model analysis was an average score analysis of attitude and readiness of all question attribute (Wardani et al., 2001).

$$
A_{0}=\sum_{i=1}^{n}\left[b_{i}\right] x\left[e_{i}\right]
$$

Where: $A_{0}=$ Attitude and readiness toward an object; $b_{\mathrm{i}}=$ Believe rate that an object had attribute I; $e_{i}=$ Evaluation on attribute $\mathrm{I} ; \mathrm{n}=$ Number of prominent attribute. 
Based on Fishbein's Attitude Model test, it was known that extension officers had a positive attitude in accepting ICT. The score was 52,45 rank somewhere between neutral and positive value (42-56) in the interval of 14-70. Test on farmers' readiness in accepting ICT was negative until neutral with score 13,98 (10-15) in interval 5-25, infrastructure readiness to accept ICT tended to neutral with score 10,23 laid between neutral until positive value (9-12) in interval 13-15, management support/ readiness in accepting ICT was also positive with score 11,72 between neutral until positive (9-12) in interval 13-15, culture readiness to accept ICT was relatively positive with score 14,58 between neutral until positive (12-16) in interval 4-20, and ICT acceptance was positive with score 44,43 between neutral until positive (36-48) in interval 12-60. Based on the explanation, it could be inferred that attitude, extension officers' readiness, infrastructure readiness, management support/readiness and culture readiness tended to be neutral until positive which meant that respondents was relatively easy to accept ICT in Boyolali District, while farmers' readiness tended to be negative until neutral which meant that farmers were ready enough to accept ICT in Boyolali District.

The equation was $Y=-6,234+0,211 X 1+0,213 X 2+0,550 X 3+0,119 X 4+1,252 X 5+$ 0,665X6 (Table 2).

Table 2 - Multi Linear Regression Analysis Result

\begin{tabular}{llll}
\hline Variable & Regression Coefficient & t count & (sig t) $\alpha=0,05$ \\
\hline XI (Officer's attitude ) & 0,211 & 2,071 & $0,043^{*}$ \\
X2 (Farmer's readiness) & 0,213 & 1,278 & 0,207 \\
X3 (Officer's readiness) & 0,550 & 2,149 & $0,036^{*}$ \\
X4 (Infrastructure readiness) & 0,199 & 0,568 & 0,572 \\
X5 (Management support) & 1,252 & 2,657 & $0,010^{*}$ \\
X6 (Culture support) & 0,665 & 2,090 & $0,041^{*}$ \\
\hline Constanta & $-6,234$ & & \\
F count & 44,683 & & 0,008 \\
Adjust R Square $\left(R^{2}\right)$ & 0,816 & &
\end{tabular}

Source: Data Processed, 2018.

Constant number $-6,234$ meant that there were no other variables influenced ICT acceptances, so that ICT acceptance value was $-6,234$. Coefficient X1 was 0,211 this could be assumed that when extension officers' attitude was raised $1 \%$, ICT would increase $0,211 \%$. Coefficient X2 was 0,213 this could be meant that when farmers' readiness was raised $1 \%$, ICT acceptance would increase $0,213 \%$. Coefficient X3 was 0,550 this could be meant that when extension officers' readiness was raised $1 \%$, ICT would increase $0,550 \%$. Coefficient X4 was 0,119 this could be assumed that when infrastructure support was raised $1 \%$, ICT acceptance would increase $0,119 \%$. Coefficient X5 was 1,252 this could be assumed that when management support was raised $1 \%$, ICT acceptance would increase $1,252 \%$. Coefficient X6 was 0,665 this could be assumed that when culture support was raised $1 \%$, ICT acceptance would increase $0,665 \%$. Therefore values of $X 1, X 2, X 3, X 5$ and X6 significantly influenced the ICT acceptance.

$R^{2}$ coefficient value was used to find out how suitable the model was. Adjusted $R^{2}$ was used to figure out how much the contribution of the two independent variables was. Based on Table 4 Adjusted $R^{2}$ value was 0,816 ; which meant that variables variance in accepting ICT could be explained by data variance of extension officers' attitude and readiness (farmers' readiness, extension officers' readiness, infrastructure, management support, culture support) as big as $81,6 \%$ and the other $18,4 \%$ was explained by other variables which not included in the research and they were set as disturbance's error.

Table 4 - Determination Coefficient $\left(\mathrm{R}^{2}\right)$ Calculation Result

\begin{tabular}{llll}
\hline Model R & R Square Adjusted & R Square & St. Error \\
\hline 1 & 0.914 & 0.8350 .816 & 4.23637 \\
\hline
\end{tabular}

Source: Data Processed, 2018. 
Based on Table $3 f_{\text {cal }}$ was 44,683 and was significant at $0,000<0,05$. It could be inferred that independent variables all together influenced dependent variable at level significant of $5 \%$. Based on data calculation, a conclusion could be drawn that there were influences from extension officers' attitude and readiness (farmers' readiness, extension officers' readiness, infrastructure, management support, culture support) toward ICT acceptance simultaneously.

Table 3 - F Test Calculation Result

\begin{tabular}{llllll}
\hline Model & Sum of Squares & $\mathrm{df}$ & Mean Square & $\mathrm{F}$ & Sig \\
\hline Regression & 4881.552 & 6 & 801.925 & 44.683 & $000^{\mathrm{a}}$ \\
Residual & 951.181 & 53 & 17.947 & & \\
Total & 5762.733 & 59 & & & \\
\hline
\end{tabular}

Note: Data Processed, 2018.

From research result (Table 5), it was known that extension officers' attitude significantly affected the ICT acceptance with the value of $p=0,043, t$ table in df 53 at the level of confidence $95 \%$ was 2,00575 . This was in line with Herawati (1999) who stated that attitude was willingness to act and not an implementation of a certain motive. An attitude was not a action or an activity, but a predisposition of an action or a behavior. An attitude was not necessarily be implicated in an action. The realization of an attitude into a real action needed supporting factor or certain condition to enable the realization, namely facility. Therefore, ICT acceptance was influenced by the attitude of extension officers because when the officers were not ready in using the communication and information technology, it would obstruct the ICT acceptance.

Table 5 - t Test Calculation Result

\begin{tabular}{lllll}
\hline Variables & Value t count & Value t Table & Sign P & Result \\
\hline XI (Officer's attitude ) & 2.071 & 2,00575 & 0.043 & Significant \\
X2 (Farmer's readiness) & 1.278 & 2,00575 & 0.207 & Not Significant \\
X3 (Officer's readiness) & 2.149 & 2,00575 & 0,036 & Significant \\
X4 (Infrastructure readiness) & 0.568 & 2,00575 & 0.572 & Not Significant \\
X5 (Management support) & 2.657 & 2,00575 & 0.010 & Significant \\
X6 (Culture support) & 2.090 & 2,00575 & 0.041 & Significant \\
\hline
\end{tabular}

Note: Data Processed, 2018.

Farmers' readiness did not significantly affect the ICT acceptance with $p=0,207$, t table with df 53 and level of confidence $95 \%$ was 2,00575. This was caused by the lack of education among the farmers and the absent of training in using communication and information technology. ICT usage was emphasized for extension officers so that the information and knowledge they got would be delivered to the farmers to increase their crop production. Mardikanto and Sutarni (1996) mentioned that education level would affect one's mindset and skill in handling a work and one's acceptance toward changes and innovation then also the implementation.

Extension officers' readiness significantly affected the ICT acceptance with $p=0,035, t$ table in df 53 and level of significant $95 \%$ was 2, 00575. Readiness was a competency which meant when someone had a competency, he would be ready to do something (Arikunto, 2001). Readiness was all condition which made someone ready to give response or answer in a certain way toward a certain situation. Condition adjustment would someway influence the response tendency (Slamento, 2010). From those theories, it could be inferred readiness was a condition someone or an institution had in preparing itself mentally and physically to achieve the target. The adequate condition when agriculture extension officers have learnt the usage of ICT and then be able to operate computer and use the internet would ease their work as extension officers.

Infrastructure readiness did not influence significantly toward ICT acceptance with $p=0,572$. T table with df 53 and level of confidence $95 \%$ was 2, 00575. Infrastructure 
readiness was not in line with implementers' readiness, thus would not influenced the ICT acceptance. Most of infrastructure only gave facilities but did not give the needed training in using the communication and information technology. Such training could be obtained from non formal education in certain institution.

Management support significantly influenced the ICT acceptance with $p=0,010$, t table in df 53 and level of confidence 95\% was 2, 00575. This meant that the absent of management support would complicate ICT acceptance, because a good management was not only supported by facilities but also a training related to the facility usage. Extension officers who were able to use ICT would be obstructed when the management did not support, therefore management support to give facilities and internet access for extension officers would affect ICT acceptance. Management was a process or a framework which involved guidance and direction for a group of people toward organizational goals or real aims (Terry and Lesly, 2003).

Culture support in agriculture department significantly influenced ICT acceptance with $p=0,041$, t table in df 53 and level of confidence $95 \%$ was 2, 00575, because culture gave quite big influence toward one's behavior. Today's environment where people were all familiar with ICT usage would require one to accept communication and information technology. Thus the one would learn how to use computer and internet. Surrounding culture that has already used internet would give a lot of information through online media, such as email and other social media. For those who could not access internet would suffer an impact toward their social life and toward their work environment. According to Williams (1983) culture was a general process of intellectual, spiritual and aesthetical development. Culture could also mean a certain way of life of a certain group, period or citizen.

Based on table 6 , tolerance value was less than 0,1 or VIF value was not more than 10 , therefore there was a multicollinearity and the regression resulted did not consist of intercorelated independent variables or the regression has passed the multicollinearity test. Multicollinearity could be identified from tolerance value or Variance Inflation Factor (VIF) value. The limit of tolerance value was less than 0,1 or VIF value was not more than 10 which meant there was a multicollinearity. Multicollinearity caused standard error to become bigger and increase the correlation among the independent variable (Ghozali, 2007). Heterocedacity test was done to find out if there was a heterocedacity, by identifying if there was a certain pattern on the scatterplot which showed a relation between Regression Residual and Regression Standardized Predicted Value (Santoso, 2001).

Table 6 - Multicollinearity Test Result

\begin{tabular}{lllll}
\hline \multirow{2}{*}{ Variables } & \multirow{2}{*}{ N } & \multicolumn{2}{c}{ Collinearity Statistics } & Result \\
\hline XI (Officer's attitude ) & 60 & 0.207 & 4.834 & Free Multicollinearity \\
X2 (Farmer's readiness) & 60 & 0.834 & 1.199 & Free Multicollinearity \\
X3 (Officer's readiness) & 60 & 0.308 & 3.242 & Free Multicollinearity \\
X4 (Infrastructure readiness) & 60 & 0.372 & 2.692 & Free Multicollinearity \\
X5 (Management support) & 60 & 0.248 & 4.034 & Free Multicollinearity \\
X6 (Culture support) & 60 & 0.341 & 2.934 & Free Multicollinearity \\
\hline
\end{tabular}

Note: Data Processed, $2018 ю$

\section{CONCLUSION}

Based on research results, some conclusions were withdrawn that firstly, Agriculture extension officers' attitude in Boyolali District tended to be positive to ICT acceptance. Secondly, Agricultural extension officers and infrastructure readiness, management and culture support tended to be positive to ICT acceptance, while farmers' readiness was negative until neutral. Thirdly, Agriculture extension officers' attitude and readiness, culture and management support individually influenced in a positive way toward ICT acceptance. Finally, Agriculture extension officers' attitude gave positive influence toward ICT acceptance; this meant the more positive the attitude and readiness of extension officers, the higher ICT acceptance. 


\section{REFERENCES}

1. Akpabio, I.A., Okon, D.P. \& Inyang, E.B. 2007, "Constraints affecting ICT utilization by agricultural extension officers in the Niger Delta, Nigeria", The Journal of Agricultural Education and Extension, vol. 13, no. 4, p. 263-272.

2. Arikunto. S. 2001. Prosedur penelitian. Jakarta: Rienka Cipta.

3. Departemen Pertanian, 2006. Undang-Undang Republik Indonesia Nomor 16 Tahun 2006 Tentang Sistem Penyuluhan Pertanian, Perikanan and Kehutanan, Jakarta.

4. Gujarati, D. 1999. Basic Econometri. Penerbit PT Erlangga. Jakarta.

5. Ghozali. I. 2007. Aplikasi Analisis Multivariant dengan Proses SPSS. Universitas Diponegoro Press. Semarang.

6. Herawati. 1999. Dasar-Dasar Komunikasi untuk Penyuluhan. Universitas Atma Jaya, Yogyakarta.

7. Koehnen TL (2011) Book reviews: ICTs for agricultural extension. Global experiments, innovations and experiences. Journal of Agricultural Education and Extension. 17(5): 473-477.

8. Mardikanto, T and Sutarni. S. 1996. Penyuluhan Pembangunn Pertanian. UNS Press Surakarta.

9. Nani, S. 2008. Kinerja Penyuluh Pertanian Di Jawa Barat. Job Performance of Agricultural Extension Agent In West Jawa Province. Pusta Jurnal IPB. Bogor.

10. Purnomo SH and Lee $\mathrm{YH}$ (2010) Assessment of readiness and barriers towards ICT program implementation: Perceptions of AEO in Indonesia. Int. Journal of Education and Development using Information and Communication Technology 6(3): 19-36.

11. Santoso, S. 2001. Buku Latihan SPSS Statistic Parametrik, Alex Media Komputer, Jakarta.

12. Sunyoto, D. 2009. Analisis Regresi and Uji Hipotesis. Penerbit Angkasa. Bandung

13. Slamento, 2010. Kamus Besar Bahasa Indonesia, Penerbit Kanisius. Komunikasi; Materi Pokok Modul Universitas Terbuka, Jakarta: UT.

14. Sugiono. 2005. Memahami Penelitian Kualitatif. Alpabeta, Bandung.

15. Terry, George R., Lesli W R. 2003. Dasar - Dasar Manajemen. Jakarta. PT Bumi Aksara.

16. Unang, Y. and Didin, S. T. 2001. Peran Penyuluh Dalam Proses Pembelajaran Teranak Sapi Perah di KSU Tandang Sari Sumedang. Fakultas Pertanian Padjajaran. Bandung.

17. Wardani N. Budi S., Agustina S.H.W. 2001. Analisis Sikap and Perilaku Pembaca Surat Kabar Terhadap Susu Kedelai. Universitas Brawijaya

18. Williams, R. 1983. Keywords: A Vocabulary of Culture and Society. London: Fontana. 